\title{
PERFORMANCE MANAGEMENT SYSTEMS IN PUBLIC SECTOR UNDER NEW PUBLIC MANAGEMENT REGIME: AN AUSTRALIAN CASE
}

https://doi.org/10.47743/jopafl-2021-20-03

\author{
Anup CHOWDHURY \\ Department of Business Administration, East West University, \\ Dhaka, Bangladesh \\ anup@ewubd.edu \\ Nikhil Chandra SHIL \\ Department of Business Administration, East West University, \\ Dhaka, Bangladesh
}

\begin{abstract}
Performance management system in public sector has undergone significant changes in new public management regime. Countries adopting new public management have brought changes in styles and modalities of performance management in public sector with the sole purpose of ensuring service quality to the satisfaction of service recipients. This research has adopted a qualitative research methodology under epistemological and ontological paradigm of social inquiry to study the performance management system of a government owned department in Australian Capital Territory. Giddens' Structuration theory has been applied as theoretical framework to develop a thick description of social reality. An in-depth case study method has been used as a predominant research methodology supplemented by observation, interview and review of archival records. The study reveals that new public management ideology has been successful in ensuring performance of the department from multi-facet dimensions.

Keywords: Case Study; Giddens' Structuration Theory; New Public Management; Performance Management System; Public Sector Organization
\end{abstract}

\section{Introduction}

During the last three decades, the public sector worldwide has come under increasing pressure to improve performance and demonstrate greater transparency and accountability (Alam and Lawrence, 1994; Parker and Bradley, 2000; Larbi, 2003; Brown et al. 2003; Ellwood and Newberry 2007, Evans, 2018). In this context the practitioners started to adopt new management approaches as the basis for improving performance in the public sector (Metcalfe and Richards, 1992; Osborne and Gaebler, 1992; Hughes, 1995; Girishankar, 2001; Robbins, 2007; Christiaens and Rommel, 2008; Broadbent and Guthrie, 2008; Alam and Nandan, 2008; Dooren et al., 2010; Walker and Boyne, 2010; Hoque and Adams, 2011; Kearney, 2018). This management approach created a new orthodoxy in the public sector, namely 'new public management' (NPM) (Hood 1991, 1995; Dunleavy and Hood, 1994; Hoque 2005, 2008; Alam and Nandan, 2008; Yusuph and Guohua, 2017). The NPM movement has emphasised the value of market efficiency in the public sector and stimulated various managerial reinventions (Moon, 2000; Tooley, 2001; Luke, 2008; Christiaens and Rommel, 2008). The NPM initiatives forced public organisations to concentrate on a new approach focusing people within the organisation. The objective to 
introduce this new management approach in the public sector is to promote a culture of performance (Baehler, 2003; Mir and Rahaman, 2006; Jansen, 2008). It ensures learning environment and professional development within the organization. In line with the NPM reforms, public organisations are now using a number of people control mechanism similar to the private organisations. In an organisation people control mechanism provides three fundamental purposes. First, it helps to make sure that each employee understands organization's expectations. Second, it helps to make sure that each employee is capable to do a good job. The third purpose is to make sure that each employee will engage in self monitoring (Widener, 2004; Davilla, 2005; Merchant and van der Stede, 2012). Performance management system is an element of a people control system which is a part of overall management control systems of an organization. Performance management is a formal and regular process for assessing and managing individual performance for all employees (Australian National Audit Office, 2004/05).

Kimura and Mourdoukoutas (2000) argued that management control systems must be expanded to managerial practices that cultivate employee cooperation and creativity in the discovery and exploitation of new business opportunities. Chenhall and LangfieldSmith (2003) pointed out that Management control systems comprise a variety of control mechanisms, including performance management, to align individuals' behaviours with the strategies and goals of the organisation. Therefore, the purpose of management control systems is to facilitate goal congruence between an organisation and the people within it (Picard and Reis, 2002). Kareeman and Alvesson (2004) observed that people nowadays live and work under constant performance evaluation. Performance management is important not only for the effectiveness of strategic planning of the organization but also for modernization and public services reforms generally (Joyce, 2007; Anderson, 2008). During the 1980s Australia rejected traditional administration which was replaced by reforms based on management. In the 1990s new agenda emerged centered on competition and contestability, contracting out, client focus, application of purchaser/provider principle (Halligan, 2009). In 2000 integration and performance phase emerged and the focus is on attaining more effective performance management (Halligan, 2009). McCann (2001) pointed out that a firmly established performance culture in the Australian public sector has emerged and the basic notion - a public sector driven to perform - has become an integral part of everything. In the light of the wide ranging reforms and implementing new public management approach to the Australian public sector the present study intends to identify and explore the performance management system that have been implemented in a public sector organisation in Australia.

\section{Research Questions}

Berry et al. (2009) claimed that from the 1980s onwards, new public management reforms have introduced different management control tools in the public sector organizations which are borrowed from the private sector. These reforms open the door to more dynamic, action research type activities to observe the consequences of performance management systems design and its use over a period of time following a change. Traditionally, the key focus of management control research is on financial control and little attention has been paid on the components of people control. Against this background this research will explore the performance management system- a tool of people control 
system adopted in the public sector in the context of new public management initiatives. A government department in the Australian Capital Territory (ACT) has been adopted as a field for investigation for the purpose of this exploration.

The study will seek answers of the following research questions:

How has the researched organisation adopted performance management systems within their organisation? Specifically,

In what ways are performance management systems linked to the organisational actions of the researched organisation?

How have performance management systems contributed to and shaped new organisational culture within the researched organisation?

Berry et al. (2009) also suggested that much more case research is necessary to yield insights into how organisation can develop effective rules and procedures and encourage managers to act flexibly, share information and create opportunities for learning. Taking into this view and to address the research questions the present research was conducted through a case study.

\section{Research Method}

This research explored in depth the evolution of performance management system in the context of new public management initiatives in Australia. The organisation investigated under this study was a government department in the Australian Capital Territory (ACT) involved in service delivery. This department was formed in 2002 to assist people with disability, and to cater to needs in housing and community services. The qualitative research approach was adopted and data was collected in the ethnographic tradition. By using qualitative research methodology, this study is something like naturalistic inquiry (Guba and Lincoln, 1981) which has provided a thick description (Geertz, 1973). In this research the sources of data were: official organizational documents, interviews and observations.

Documents allow the researcher to track what happened, when it happened, and who was involved (Bickman and Rog, 2009). In this research, the researched department supported the researchers in collecting official organisational documents and archival records. One of the researchers spent more than one year in the selected organization. The department provided the researcher with a desk and a personal computer to collect the necessary information. The department allowed the researcher to use staff intranet which made it easier for the researcher to collect internal evaluation reports, financial delegation manuals, newsletters and numerous other organisational documents. The researcher maintained a high level of confidentiality in this regard. Approximately 5000 pages of official organisational documents were collected during the research. These official documents helped the researchers to supplement and corroborate the interview data. Observation data come from detailed descriptions of people's activities, actions, behaviours, interpersonal interactions and organisational processes (Patton, 2002). Patton asserted that observation data is sufficiently descriptive and the reader can easily understand what occurred and how it occurred. Observation can also be used to overcome validity threats because it focuses on actual behaviour not perceptions (Birnberg et al. 1990). Observation can be done in four ways. These are: complete observer, complete participant, observer as participant and participant as observer (Pearsall, 1970; Denzin, 
1978a; Atkinson and Hammersley, 1994; Denzin and Lincoln, 2003, 2008; Cohen et al. 2007; Flick, 2009; Stake, 2010; Rallis and Rossman, 2012). The researcher can take any of the abovementioned roles. In this research, the researcher played the 'participant as observer' role because by adopting this role, the researcher was able to collect more indepth data, which was the prime objective of this study. Data were collected in the field notes. All field notes were dated with appropriate reference number, time, place, attendees and researcher's opinion towards the situation. The departmental staff with whom the researcher came into contact was very co-operative and seemed really interested in this study. The epistemological position influenced the researcher to conduct interviews because it allows a legitimate or meaningful way to generate data by talking interactively with people, to ask them questions, to listen to them, to gain access to their accounts and articulations, or to analyze their use of language and construction of discourse (Mason, 2002). The primary interview method used in this study was unstructured and open-ended. In this study snowball sampling technique was used. To conduct the interviews in this research, 20 top and mid-level executives and junior staff were included in the interviews. The intention was to include participants ranging from lower positions to upper management positions to obtain a complete understanding about the perceptions.

Any research involving human and animal subjects requires ethical clearance from the relevant institution (Hoque, 2006). The present research, as it involved human subjects, was approved by the Committee for Ethics in Human research at the University of Canberra, Australia. It followed the general conditions determined by the university policy and the National Statement on Ethical Conduct in research involving Humans (National Health and Medical Research Council, 1999). To understand the purpose of the research project, each of the participants was provided with a Participant Information Form which included the project title, details of the researcher and the supervisors, project aim and benefits, general outline of the project, participant involvement, confidentiality, anonymity, data storage system, ethics committee clearance and queries and concerns about the research project. Each participant was also provided an Informed Consent Form. Before conducting the formal interview, the participant was required to sign the Consent Form stating that the participant understood the information about the research. Both the Participant Information Form and the Informed Consent Form were approved by the Committee for Ethics in Human Research, University of Canberra. Participation in this research was voluntary. The interview proceedings were tape recorded with the consent of the participant. For safety reasons, back-up notes were also taken and checked and compared when the transcriptions were made. The interview tapes were transcribed later word for word. Key interview transcripts were fed back to the respective interviewees to establish the validity of the interview data. In qualitative inquiry, data collection is not an end. It requires analysis, interpretation and presentation of findings (Patton, 2002; Irvine and Gaffikin, 2006; Merriam, 2009; Nagy et al. 2010). In this study, the researcher analyzed data using the approach provided by Miles and Huberman (1994) which includes data reduction, data display and conclusion drawing and verification.

\section{Theoretical Framework}

Gaffikin (2007) argued that research is undertaken to either generate new theories or support existing theories. It has been observed that there are various views among the 
researchers in adopting a prior theoretical stance in research. Some scholars argued that a prior theoretical stance may bias or limit the findings (Eisenhardt, 1989; Flinders, 1993; Layder 1995). The critics claimed that adopting a pre-determined theory in a research can be more robust because these theories have already been tested in previous research. However, supporters in favour of adopting a prior theoretical framework in research (for example Alam and Lawrence, 1994; Lodh and Gaffikin, 1997; Quattrone and Hopper, 2001; Baxter and Chua, 2003; Hoque, 2005; Gaffikin, 2007; Berry et al. 2009) argued that in conducting research on organisational practices, it is legitimate to use a wide range of theoretical approaches to explain such activities. In qualitative research, a useful theory helps to organise the data (Jorgensen, 1989; Lodh and Gaffikin, 1997; Llewelyn, 2003; Irvine and Gaffikin, 2006; Cooper, 2008; Maxwell, 2009, Jacobs, 2012). The view taken in the present research assumes that theory is a framework for viewing the social world that is too general, too broad and too all-encompassing to be confirmed or refuted by empirical research (Cooper, 2008). It is also assumed in this research that when knowledge is gathered with the help of theory, there is a potential for data coherence and control, which prevent the researchers from collecting an unsystematic pile of accounts (Kaplan and Manners, 1986; Bogdan and Biklen, 1982).

Over the last two decades it was observed that a series of alternative approaches has been used in qualitative research. One of these approaches is motivated by interpretive sociology (Glaser and Strauss, 1968; Schutz, 1967). Interpretive perspective epistemologically believes that social meaning is created during interaction and people's interpretations of interactions (Hesse-Biber and Leavy, 2006; Cresswell, 2007; Gaffikin, 2008). Chua (1988) argued that interpretive sociology refers to an intellectual tradition which focuses on the constructive and interpretive action of people. Llewelyn (2003) observed that qualitative research using interpretive methodologies now has become increasingly influential. According to these methodologies, performance management system is not natural phenomena they are socially constructed and they can be changed by social actors (Ryan et al., 1992). Interpretive approaches illustrate the subjective nature of the social world and tries to understand it primarily from the frame of reference of those being studied (Hopper and Powell, 1985). Humphrey and Scapens (1996) found that published management control researches have been influenced by these interpretive approaches of writings of social theorists and philosophers. Management control researchers adopted these theories to analyse sociological and philosophical discourse (Zawawi and Hoque, 2010). They used various sociological and philosophical theories, for example, theories provided by Focault, Latour, Marx, Adorno, Braverman, Gramsci, Hebermas, Giddens, Weber and Derrida. These theoretical stances helped to understand issues of social control and coordination (Covaleski and Dirsmith, 1990; Covaleski et al., 1996; Lodh and Gaffikin, 1997). In order to gain a better understanding about the control systems in an organisation, it is necessary to look at the relationship between day-to-day social action and the various dimensions of social structure. The present study has adopted an interpretive approach and used Giddens's structuration theory to understand how results control systems, one of the important management control systems, is implicated in their social setting. The epistemological and ontological belief also inspired the researchers to adopt Giddens' structuration theory in this study. Here, it is assumed that multiple realities can exist in a given situation and for this reason the intention of the research is to promote a subjective research. The following Figure shows Giddens's structuration framework. 
Figure 1. Structuration framework

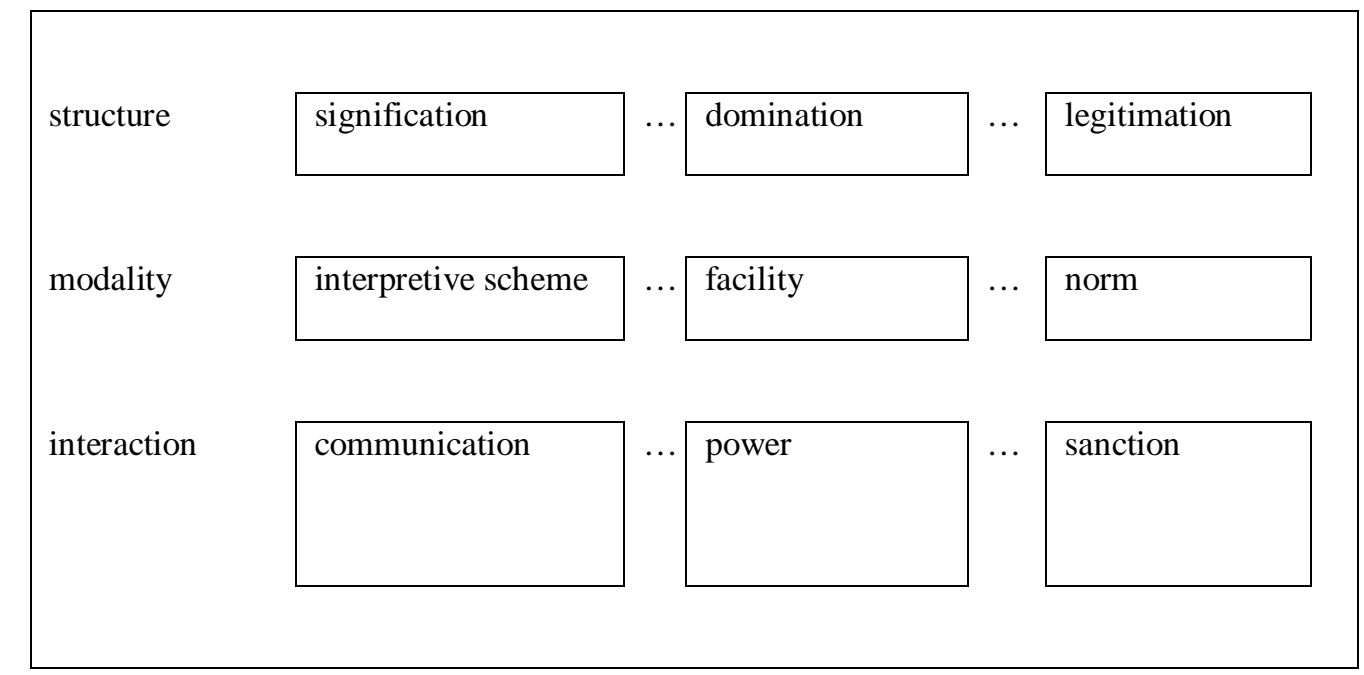

Source: Giddens, 1984, p.29

The third line of the Figure refers to the elements of interaction: communication, power and sanction. Second line represents modalities which refer to the mediation of interaction and structure in processes of social reproduction (Giddens, 1984, p. 29). Here modalities are interpretive scheme, facility and norm. Those on the first line are characterisations of structure in the form of signification, domination and legitimation. Signification refers to the communication of meaning in interaction. It is the cognitive dimension of social life which has interpretative schemes. Interpretive schemes are 'standardized elements of stock of knowledge, applied by actors in the production of interaction' (Giddens, 1984, p.30). In the signification structure, agents draw upon interpretative schemes in order to communicate with each other and at the same time reproduce them. In the domination structure the use of power in interaction involves the application of facilities. The facilities are both drawn from an order of domination and at the same time, as they are applied, reproduce that order of domination (Giddens, 1984, p. 30). The final structure is that of legitimation which involves moral constitution of interaction, and the relevant modality here is the norms of a society or community which draw from a legitimate order, and yet by that very constitution reconstitute it (Giddens, 1976, p. 123). These three structures constitute the shared set of values and ideals about what is important and should happen in social settings. Giddens (1976, 1979, and 1984) identified that actors are not simply as social dupes governed by independent structures, but rather as existential beings who reflexively monitor their conduct and make choices in social settings.

\section{Findings and Discussion}

A central element in the Australian public sector reform policy during the last thirty years is management for results based on performance. It has created a culture of clear and precise definition of program and organisational objectives for the Australian public sector managers. Managers in the Australian public sector established control system within their organisation to influence the employees' actions. The objective to implement this control 
system is to inform the employees about the goals of the organisation. Evidence from the field supported that the researched organisation has benefited enormously in adopting a performance approach to management.

Findings of the study reveals that in line with the NPM initiatives, the researched organization built a participative and consultative workplace where people want to work and stay in the organisation. They provide staff with opportunities for professional development and support learning environments. The following quote illustrates this view:

We will maximize and maintain the Department's human resource capacity. We will support and provide opportunities to our staff and other personnel to provide a responsive and responsible workforce (DHCS, 2007a, p. 15).

The Organisational Services Unit of the Department provides strategic advice in relation to People Management. This unit also prepares human resources planning and develops personnel control systems within the organisation. To implement people, control first it focuses on staffing the organisation. It is the process by which the department satisfies their human resources needs. In the department the strongest influences on culture formation are top management's day-to-day activities, interactions, sentiments and norms. The department has applied a wide range of cultural control devices which are reflected within its operations. These devices are supported by organisation-wide norms and values and shaped organisational culture within the organisation. In the researched organization, it is evident that performance reviews and staff appraisal were introduced in the line of the new public management.

The researched organization designed people control systems across all its units to fit organisational basic needs, core values, and strategic goals. To assist managers and staff in implementing performance management, the department developed its Guide to Performance Management. This was clear from the comments made by the Chief Executive of the department:

The Introduction of a Performance Management Program in the Department is an integral step to ensure that we meet our strategic goals and performance measures. I strongly support the introduction of the program as I believe that employees have the right to receive regular feedback on their performance and to understand how their work helps the Department to achieve its strategic goals and ensure the ongoing development of staff (DHCS, 2007c).

The researched organization's documents show that according to the guideline, a key driver in implementing the performance management program is to encourage managers/supervisors to talk to staff in a more formal process to ensure ongoing communication, expectations, development and the alignment of individual goals with departmental goals and performance measures (DHCS, 2007c). The performance management program of the Department is intertwined with the legitimation structure. Legitimation involves the moral constitution of the interaction (Giddens, 1979; 1984). In the researched organization, this legitimation structure is mediated through normative values and ideals about approve and disapprove behavior.

It is evident that performance management is addressed in the Department as performance culture. The benefits and goals of performance management in the Department are:

- the ability for employees to develop a clear picture of the employees' role and purpose within the Agency; 
- the establishment of improved communication between employees, supervisors and managers; and

- the ability to explore and develop the skills and potential of employees (DHCS, 2007b).

The researched department claims that their performance management program benefits the business because it has clear definition of roles and responsibilities and improves staff communication (DHCS, 2007c). It also focuses on achieving business goals. Evidence from the field and organisational documents suggests that in the line of the new public management the Department is trying to establish a performance-oriented culture that focuses on outcomes as well as process. One of the senior executives of the Department elaborated:

- We have established a performance-oriented culture and put emphasis on the application of performance management system. This program is based on results and designed to improve transparency in a new public sector environment. Basically, this system focuses on strategies and activities of the Department with the individual responsibilities. We are at the initial stage in implementing this tool and struggling a lot.

The operation of this performance management program in the researched organization includes five steps. This practice is different from the private sector.

Figure 2. Performance Management Program in the researched organization

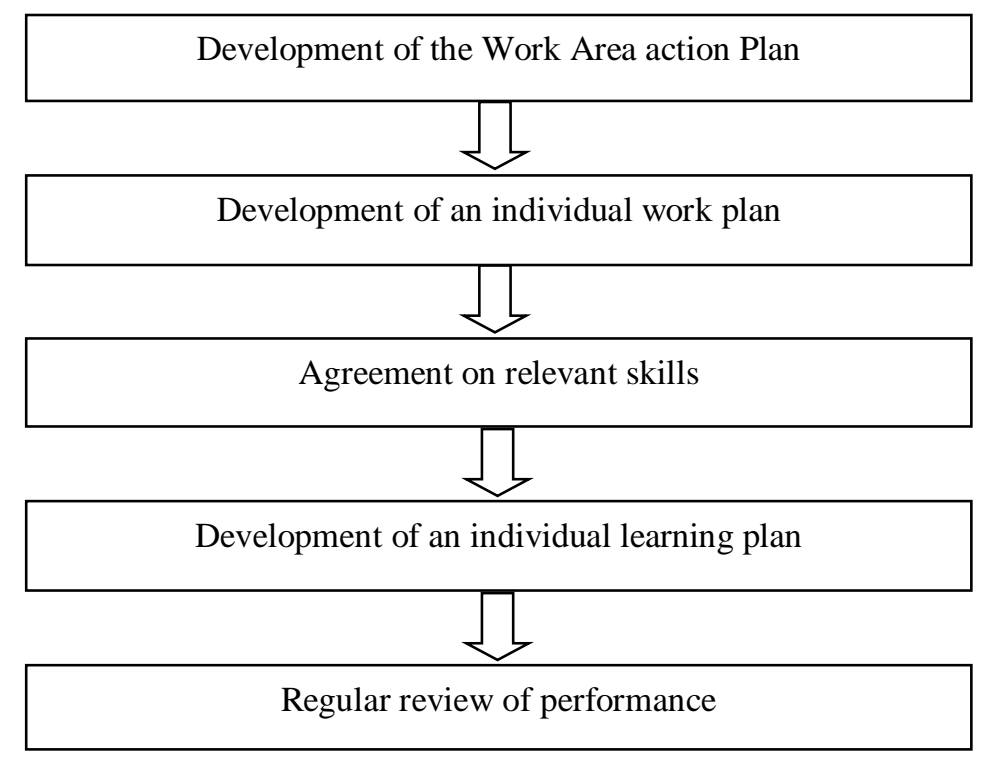


One of the senior executives of the department made the distinction of performance between private and public sector and highlighted the fact that traditionally this practice would not occur in the private sector. He commented: If you compare performance between private and public sector, within the private sector one of the goals is to achieve profit for the organisation, which they might allow to share profits across the management and staff team. In the public sector our goal is to be efficient and effective with public money and that is the challenge.

At step three the skills, knowledge and behavior needed to carry out the responsibilities of the position and to work effectively with others are also identified. Then staffs are required to identify the area where improvement is needed and records it in the Individual Learning Agreement. Finally, a meeting is conducted between the supervisor and the staff and a performance review document is prepared (a copy of performance review agreement is attached in Appendix I). Under the performance management program of the Department, formal feedback takes place at least every six months, conducted usually in May/June and November/December (a copy of feedback on performance is provided in Appendix II). This formal feedback ensures that progress against the plan is acknowledged and recorded and plans are still realistic and reflect changes in directions and priorities. If any training and development activities are needed, it is carried out according to this feedback. It is evident that in addition to formal feedback there are also informal feedback systems in the department. This informal feedback is conducted to ensure that the progress is satisfactory. It also identifies the areas where improvement may be necessary. Evidence from the field shows that the Department always recognizes and acknowledges good performance. However, poor performance is addressed early and not left until the formal feedback session. The relevant area manager offers advice and support to the employee to overcome unsatisfactory work performance.

A review of organisational documentation suggests that the Department also developed an action plan for poor performance of employees. If the manager considers that an employee's work is not satisfactory, the manager discusses his/her concerns with the employee. If the problem continues, the manager informs the employee in writing the assessment and prepares an action plan. This action plan is developed in consultation with the employees. The department identified the possible causes of poor performance and also developed possible solutions for poor performance. This practice is also different from the private sector where staffs are simply terminated for poor performance. In the department there are different alternatives to implement this program and are more flexible than the private sector.

Table 1. Causes of unsatisfactory performance and probable solutions

\begin{tabular}{|c|c|}
\hline $\begin{array}{c}\text { Cause of poor performance } \\
\begin{array}{c}\text { Employee has personal } \\
\text { financial problems etc. }\end{array}\end{array}$ & $\begin{array}{c}\text { Meet with the employee and establish if there are any problems. } \\
\text { Suggest employee should meet with the Employee Assistance } \\
\text { Program (EAP) provider. Employer may be able to offer alternate } \\
\text { work arrangements to assist the employee during a difficult period. }\end{array}$ \\
\hline $\begin{array}{c}\text { Employee doesn't know what } \\
\text { is expected }\end{array}$ & Establish standards, expectations and/or objectives. \\
\hline
\end{tabular}




\begin{tabular}{|c|c|}
\hline $\begin{array}{l}\text { Employee doesn't know how } \\
\text { to do what is expected }\end{array}$ & $\begin{array}{l}\text { Arrange for training. Look into the availability of reference materials } \\
\text { and other aids. }\end{array}$ \\
\hline $\begin{array}{l}\text { Employee knows how to do } \\
\text { what is expected but is 'out of } \\
\text { practice' }\end{array}$ & Provide practice \\
\hline $\begin{array}{l}\text { Employee doesn't get } \\
\text { feedback about the level and } \\
\text { the quality of actual } \\
\text { performance }\end{array}$ & $\begin{array}{l}\text { Establish some means of giving timely feedback. This could be } \\
\text { through periodic discussions with the employee or regular meetings } \\
\text { of all staff. }\end{array}$ \\
\hline $\begin{array}{l}\text { Expected performance is } \\
\text { difficult, 'punishing', or in } \\
\text { some way less desirable for } \\
\text { the employee }\end{array}$ & $\begin{array}{l}\text { Remove or reduce the inhibiting factors to correct performance. Try } \\
\text { to make good performance be seen as important. }\end{array}$ \\
\hline $\begin{array}{l}\text { Something in the work } \\
\text { environment interferes with } \\
\text { performance }\end{array}$ & $\begin{array}{l}\text { Determine the source of interference by looking at priorities, time } \\
\text { expectations, mix of duties, physical environment, compatibility with } \\
\text { other workers or availability of resources. }\end{array}$ \\
\hline $\begin{array}{l}\text { Performing below } \\
\text { expectations is easier, } \\
\text { 'rewarding', or in some way } \\
\text { more desirable for the } \\
\text { employee }\end{array}$ & $\begin{array}{l}\text { Be sure expectations are known and the consequences for not } \\
\text { performing up to expectations are also known (effect on future } \\
\text { performance appraisals, employee's displeasure interference with } \\
\text { others’ work). See if the performance as expected can be made less } \\
\text { difficult or more rewarding. }\end{array}$ \\
\hline
\end{tabular}

In terms of performance, the researched organization has developed management control systems. The department rewards good performance or punishes poor performance. The elements of punishment as a management control device may be by way of demotion, supervisor disapproval, and failure to get rewards earned by peers; only in extreme circumstances, an employee is punished with loss of job (Merchant and Van der Stede, 2012).

A vital element of Australian Public Sector reform initiatives is managing for results. The Australian public sector now focuses on results, outcomes and performance (Keating, 1993; English, 2002; Bevir et al., 2003; Hoque, 2008). A concern for results logically implies review from time to time of results achieved - in other words, it requires some attention to evaluation (Barrett et al., 1994). In line with these reform initiatives, the Department has developed performance culture within the organisation. Evidence from the field suggests that for poor performance, there is punishment system but no performancebased cash reward for good work. It is the common practice in the ACT Public Sector. To motivate people, the department has established group rewards and a recognition system.

\section{Performance-Dependent Rewards and Punishments}

Performance-dependent rewards and punishments are important elements of a results control system (Bruijn, 2002; James, 2006; Joborne, 2006; Mussari and Ruggiero, 
2010; Whitford, 2010; Zoghbi-Manrique-de-Lara, 2011; Soss et al. 2011; Brown and warren, 2011; Merchant and Van der Stede, 2012). Rewards are the motivational factors those influence employees' actions. Rewards remind employees what result areas are desired. It may be in the form of monetary or non-monetary compensations. Monetary incentives include salary increases or bonuses. Non-monetary compensations include promotions, job security, job assignments, training opportunities, freedom, recognition, and power. Punishments are the opposite of rewards.

The Department is committed to achieving an environment where employees feel valued for the contribution the employees make in achieving organisational goals. The department has implemented results control system to make employees conscious of the consequences of their actions. Field study data revealed that the department has introduced Chief Executive Awards for performance. The department also participates in the ACT Public Service Awards in which good performance and good approach with professionalism are recognized. The selection for awards can be either a team or an individual which is conducted every six months.

Evidence from the field also supports that based on performance, the department provides extrinsic rewards to its employees such as fair supervision, pleasant working condition, status etc. The department also provides intrinsic rewards which are personally satisfying outcomes such as achievement, recognition and responsibility. From departmental documents it is clear that the department is committed to the recognition and rewarding of employees for their contribution to the achievement of the department's objectives, but does not include rewards in the form of performance pay (DHCS, 2007b). One of the senior executives of the Department explained this view: In terms of monetary rewards, we are paid our salaries. In terms of performance we don't have a performance pay in the system. However, there are non-monetary rewards that include Chief Executive Award which is given at least twice a year. There is public recognition for achievements. There is also opportunity to attend conferences or perhaps even exchange programs. We have a couple of those programs which is also recognition of the contribution that the individual may have made within the organisation. A junior staff who has received awards for performance described: Being a government structure rewards are generally out of the question in the ACT government. I know in the Commonwealth there are performancebased rewards. We have non-monetary rewards and I think non-monetary rewards would be very much intrinsic and that would be better than nothing. Another interviewee also did not see any incentive for performance as reflected in the following quote: We don't have any incentive-based system in terms of performance payments or anything like that. It's just something that is part of our organisational culture. We want to try and improve our performance and to achieve that result.

The similar view was expressed by a senior executive of the department and she commented: The reward system is the pay system. We don't have any performance pay. There is no performance pay in the ACT government. That is something which is done within the Commonwealth system. The executives are under individual contracts. Within my performance agreement it's part of my agreement that I have to come in within budget and to meet government objectives. I don't get a performance pay for delivering that. We are on fixed term contracts and so in that sense contracts are either 3 years or 5 years usually for executives. If you don't deliver on what's in your performance agreement you would not expect to have your contract renewed. Reflecting on his area's experience one of the 
senior managers in the Finance Division of the Department remarked: When you are in the financial areas you always think about how do you reward good performance and how do you punish bad performance? Those are never easy. As the financial manager, here I always think about how I can do that! I really would like to do that because some of the managers are better than others with their management of resources. To be frank and I haven't come up with a good answer to that. I know in the commonwealth they give staff new performance bonuses, but in our organisation we don't. We don't have performance bonuses but we have performance reviews here. In my area we have a four- or six-monthly performance review where each manager does a formal review and documents it with the staff member. I think that's really important for communication.

A review of organisation documentation suggests that the department developed an action plan for poor performance of the employees. If the manager considers that an employee's work performance is not satisfactory the manager discusses the concerns with the employee. If the problem continues, the managers inform the employee in writing the assessment and prepare an action plan. This action plan is developed in consultation with the employees. During the action plan period, the manager makes assessments on a regular basis. At the end of the action plan period, if the managers assess the work performance of the employee as satisfactory, no further action is taken. If the performance is unsatisfactory, the Chief Executive takes action. It may be one or more in the form of transfer to other duties, below current salary, deferral of increment, reduction in increment point, temporary or permanent reduction in classification and salary, or finally termination of employment (DHCS, 2007c). However, field study data revealed that Department managers cannot fire people like private sector managers do. The main reason is that performance management in the public sector is not as strict as private sector.

It is evident that the department has started performance management as a management control tool. The focus of employee performance in the Department provides a basis to manage staff effectively and to deliver quality service to the clients. These benefits ensure accountability, quality improvements, good communication and achievement as identified by Macaulay and Cook (1994). The Department believes that the performance management program gives the managers the means to implement organisational goals and responsibilities. In the Department, this performance management program is regarded as the new signification dimension (Giddens, 1979; 1984) in the design of organisational structures, and in the policies and procedures used for rewarding the members of the organisation.

The Department is required to operate as a public sector organisation driven to perform. Evidence from the field supports that in the signification dimension of the Department, this performance management program is the new interpretive scheme brought in from private sector practice and the department uses it in modified form to cope with the changes in the public sector. From the above discussion, it can be concluded that the Department produced results control systems similar to the private sector but are not able to apply them in the same way as in private sector systems. The main reasons behind this is that public sector organisations are fundamentally different from private sector organisations on a number of dimensions such as diversity in their goals, access to resources, nature of the organisation and the accountability systems. Though the researched organisation is trying to change its organisational culture, it remains different from the private sector. 
Figure 3. Action Plan for poor performance of employees in the researched organization

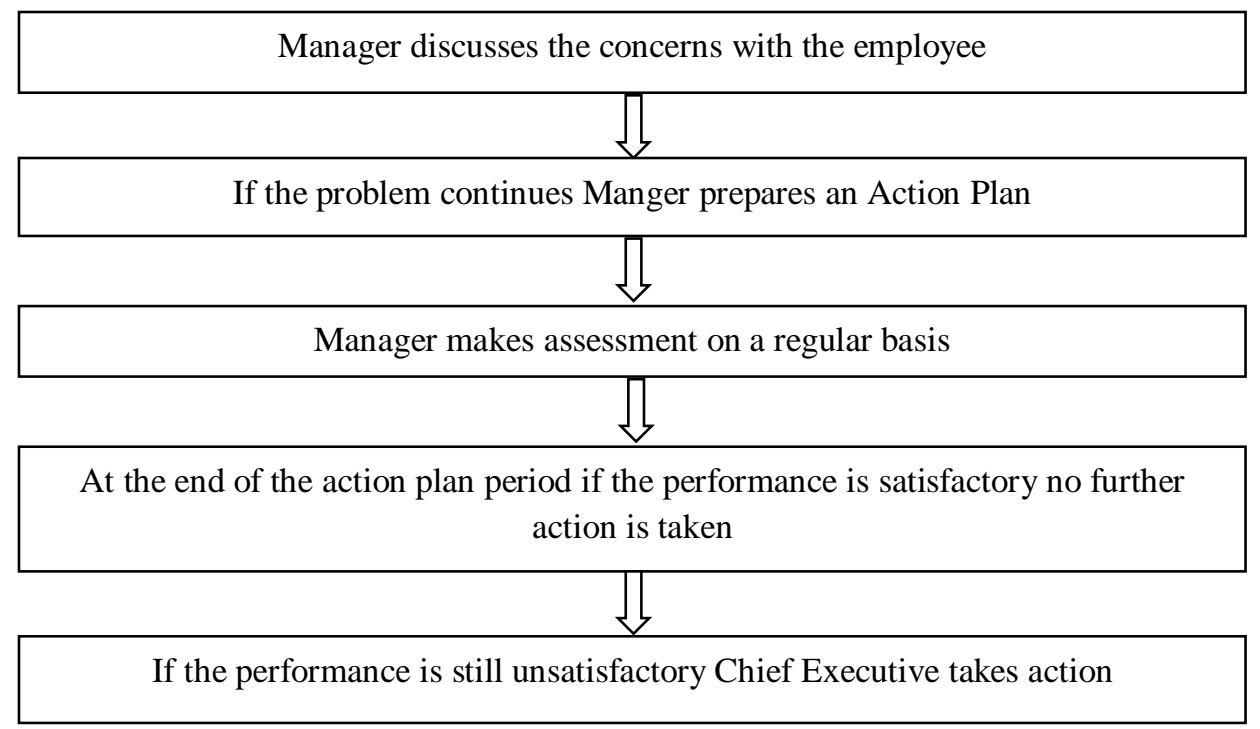

\section{Group Rewards and Recognition}

In a participatory organisation, groups and teams are empowered. Groups and teams provide a forum for making decisions, sharing information, improving functional coordination, building trust, and smoothing interpersonal relations. It creates vital links between different individuals, functions, departments, and levels of the organisation (Hellriegel and Slocum, 1991). Group rewards and recognition is considered as a management control tool and used as a key cultural control device within the Department. Giddens' structuration theory is concerned with the relationship between the actions of agents and the structuring of social systems in the production, reproduction and regulation of social order. According to Giddens (1976, 1979, 1984) group rewards and recognition is the allocative resources in the Department. The Department promotes groups and teams and this linking is evident at the various levels in the Department. The following quote illustrates this view: We will provide organisational systems, practices, procedures and policies which encourage staff to perform at their highest level in an effective team environment (DHCS, 2007a).

This finding supports the arguments of Chenhall and Langfield-Smith (2003) that team-based structures enhance employee enthusiasm to work towards sustaining strategic change. In the Department there are formal groups whose purpose and tasks are directly related to the attainment of organisational objectives. Special purpose teams are also established within the department to handle special situation. Observations during fieldwork revealed that the department developed group-based rewards and recognition for its groups and teams. It is evident that to encourage the groups or teams, the Department has introduced Chief Executive Awards for Excellence and Certificates of Commendation. This indicates the implementing of private sector culture in the public sector.

In the Department, the role played by actors and their interaction with the structure and social processes have been identified. Recognition and rewards are the allocative resources (Giddens, 1979; 1984) which the Department provides to its members. Many of the staff 
interviewed conveyed views similar to the following, expressed by a mid-level executive of Department: We have celebrations within outcomes such as the Chief Executive Awards and it's done to reward groups who have performed good jobs. The Department established this type of rewards to promote private sector performance culture throughout the organisation. It is a recognition which increases the morale of the employees also.

This finding is consistent with the results reported by O'Reilly and Chatman (1996) and Malmi and Brown (2008) that organisations provide group rewards to retain employees and encourage cultural control. This reward is given in the form of non-monetary incentives. A junior staff of Finance and Budget Division elaborated this view: I think management may provide some financial incentives. For example, in our division at the end of the financial year we all go out for a congratulatory lunch or something like that. But that's not really an incentive it's more of a moral thing than anything else. We have Chief Executive Awards but the rewards side of monetary based benefits is not there. It's more of an in lieu arrangement and we are recognized for our hard work in getting something done.

The reason behind introducing Chief Executive Awards is to build effective teams within the department and to increase employee morale also. It has also been observed that the department participates in the Commissioner for Public Administration Awards. It recognizes high achievement in the ACT Public Service and they showcase the quality and dedication of ACT Public Service employees. To build an effective team the department has not only provided different facilities for its staff but also has developed some disciplinary strategies for misconduct. This is discussed next.

\section{Misconduct and Discipline}

Blonder (2010) argued that misconduct concerns non-compliant, wasteful or illegal activities within the organisation. To ensure effective cultural control, the Department developed procedures for managing misconduct or alleged misconduct by an employee. Evidence from the field identified how the department encouraged the practical and expeditious resolution of misconduct issues in the workplace similar to the private sector. Management of the Department uses this control tool and draw upon the domination structure (Giddens, 1979; 1984) in the exercise of power.

New public management claims to use modern human resource management and asserts that employees of the public organisation will work for the interests of the public as well as for the interests of the large majority of people working in the public sector. Public servants are expected to follow the Public Sector Management Act. Misconduct happens if the employee fails to meet the obligations set out in the Public Sector Management Act. Interviews with the participants in Department indicated that sometimes this created problems. According to the Act, every member of the public service will perform to the best interest of the public. Meanwhile, their performance is measured in terms of private sector practices. It is considered a misconduct if the employee engages in behaviour or action that has or is likely to bring the department or the ACT Public Service into disrepute. If the employee returns to duty after a period of unauthorized absence and does not offer a satisfactory reason on return to work, this may be considered misconduct (DHCS, 2007b). This behaviour is consistent with the findings observed by Werbel and 
Balkin (2010) that cultural attitudes and style of communication may affect reports of unethical behaviour by employees.

The department has developed a code of conduct and established management control systems in relation to misconduct. If misconduct is alleged in the department, the manager/supervisor gathers sufficient information about it. After considering the gathered information, if it is found that the alleged misconduct has not occurred or is not sufficiently serious for further investigation, the manager or supervisor informs the employee concerned that no disciplinary action will be taken and an investigation is not necessary. However, if it is found that misconduct has occurred, but the matter can be resolved informally, then the manager or supervisor discusses it with the employee. In the investigation if it is found that serious misconduct has occurred which is against the organisational culture the Chief Executive considers disciplinary actions. From Department documentary records, this researcher found that these actions may be counseling of the employee, a written admonishment, a first or final written warning, a financial penalty, transfer to other duties at or below current salary, deferral of increment, reduction in increment point, a temporary or permanent reduction in classification/salary, and finally termination of employment (DHCS, 2007b).

\section{Conclusion}

Performance management system was found to be an integral part of the management control systems at the researched organization. Empirical evidence collected on the organisation showed that the department implemented a wide range of control mechanisms to attain the economic rationality of the NPM. The department spent considerable time since 2002 building its strengths by spreading private sector culture in a new public sector organisation in line with NPM. These cultural control mechanisms have brought economic logic into the Department's new type of management. The researchers also observed that these control devices not only supported the business culture in the Department, but has also reshaped the general orientation of the people in the Department. It is evident that in the Department these control devices are used to hold individuals accountable for their actions and behaviour. Empirical evidence collected on the organisation suggests that implementing these control devices in the Department were a response to pressures from NPM reform initiatives in Australia. The objectives of implementing these performance management systems in the Department are to facilitate goal congruence between the organisation and the people within it. The findings of this study are consistent with the view of Otley and Berry (1980): An organisation acts only by way of the actions of the individuals who comprise it. Thus, for organisational control to be effective, not only must feasible control actions be possible but individuals must also be persuaded to implement the required actions.

Giddens's structuration model was adopted to analyze the performance measurement systems of the Department and assumed this control system represents the social construction of reality. Structuration theory is a valuable way of understanding the role of the control system in the production and reproduction of the social life of any organisation. For this reason, the relationship between day-to-day social action and the dimensions in social structures were identified. The findings of the study have reported that performance management system in the Department are the modalities of structuration and 
this control system is both the medium and the outcome of interaction because in the organisational setting, this control device is constituted by human agency and at the same time also guided by them. This attitude supports the argument of Ahrens and Chapman (2007) that performance measurement system as structures both shape and are shaped by shared norms and understandings. The department has implemented this control system on a modified basis from the private sector. The department introduced rewards and punishment system in their organisation. The department is also committed to recognize and rewards employees for the employees' contribution towards the achievement of the Department's objectives but does not permit the inclusion of performance pay. However, it is evident that as a government department, the organization is committed to achieve economy, efficiency and effectiveness- the major objectives of the public sector reforms agenda by introducing new public management ideals within the organisation.

\section{References}

1. Ahrens, T. and Chapman, C. S. (2007) 'Management accounting as practice', Accounting, Organizations and Society, Vol. 32, Issue 1-2, pp.1-27. https://doi.org/10.1016/j.aos.2006.09.013

2. Alam, M. and Lawrence, S. (1994) 'A New Era in Costing and Budgeting: Implications of Health Sector Reform in New Zealand’, International Journal of Public Sector Management, Vol. 7, No.6, pp. 4151. https://doi.org/10.1108/09513559410070579

3. Alam, M. and Nandan, R. (2008) 'Management Control Systems and Public Sector Reform: A Fijian Case Study', Accounting, Accountability and Performance, Vol. 14, No.1, pp.1-28. doi/10.3316/ielapa.785038065607852

4. Andersen, S. C. (2008) 'The impact of public management reforms on student performance in Danish schools', Public Administration, Vol. 86, Issue, 2, pp. 541-558. https://doi.org/10.1111/j.14679299.2008.00717.x

5. Atkinson, P. and Hammersley, M. (1994) 'Ethnography and participant observation' in Denzin, N. K. and Lincoln, Y. S. (eds.), Handbook of Qualitative Research, Sage Publications, CA, pp. 248-261.

6. Australian National Audit Office (2004-05) 'Performance Audit Performance Management in the Australian Public Service’, The Auditor-General Audit Report No. 6, Canberra, Australia

7. Baehler, K. (2003) 'Managing for Outcomes: Accountability and Thrust', Australian Journal of Public Administration, Vol. 62, Issue 4, December, pp. 23-34. https://doi.org/10.1111/j..2003.00346.x

8. Barrett, G., Murphy, S. and Miller, R, (1994) 'Financial Management reform', in Stewart, J. (ed.), From Hawke to Keating- Australian Commonwealth Administration 1990-1993, Centre for Research in Public Sector Management, University of Canberra \& Royal Institute of Public Administration, Australia, pp. 49-68.

9. Baxter, J. and Chua, W.F. (2003) 'Alternative management accounting research- whence and whither', Accounting, Organizations and Society, Vol. 28, Issue 2-3, pp. 97-126. https://doi.org/10.1016/S0361-3682(02)00022-3

10. Berry, A. J., Coad, A. F., Harris, E. P., Otley, D. T., and Stringer, C. (2009) 'Emerging themes in management control: A review of recent literature’, The British Accounting Review, Vol. 41, pp. 2- 20. https://doi.org/10.1016/j.bar.2008.09.001

11. Bevir, M., Rhodes, R. A. W. and Weller, P. (2003) 'Traditions of governance: interpreting the changing role of the public sector', Public Administration, Vol. 81, No. 1, pp. 1-17. https://doi.org/10.1111/1467-9299.00334

12. Bickman, L. and Rog, D. J. (2009) ‘Applied Research Design’, in Bickman, L. and Rog, D. J. (eds.), The SAGE Handbook of Applied Social Research Methods, Sage Publications, London, pp. 214- 253.

13. Birnberg, J. G., Shields, M. D., and Young, S. M. (1990) 'The case for multiple-Methods in Empirical Management Accounting Research (With an Illustration from Budget setting)', Journal of Management Accounting Research, Vol. 2, Fall, pp. 32-66. 
14. Blonder, I. (2010) 'Public Interests and Private Passions: A Peculiar Case of Police Whistleblowing', Criminal Justice Ethics, Vol. 29, No. $3 . \quad$ pp. $258-277$. https://doi.org/10.1080/0731129X.2010.524039

15. Bogdan, R. and Biklen, S. (1982) Qualitative Research for Education: An Introduction to Theory and Methods, Allyn and Bacon, Boston, USA.

16. Broadbent, J. and Guthrie, J. (2008) 'Public Sector to Public Services: 20 Years of Contextual Accounting Research', Accounting, Auditing \& Accountability Journal, Vol. 21, No. 2, pp. $129-169$. https://doi.org/10.1108/09513570810854383

17. Brown, K., Waterhouse, J. and Flynn, C. (2003) 'Change management practices - Is a hybrid model a better alternative for public sector agencies?’ The International Journal of Public Sector Management, Vol. 16, No. 3, pp. 230-241. https://doi.org/10.1108/09513550310472311

18. Brown, T. C. and Warren, A. M. (2011) 'Performance management in unionized settings', Human Resource Management Review, Vol. 21, Issue 2, pp. 96-106. https://doi.org/10.1016/j.hrmr.2010.09.005

19. Bruijn, H. (2002) 'Performance measurement in the public sector: strategies to cope with the risks of performance measurement’, The International Journal of Public Sector Management, Vol. 15, No.7, pp. 578-594. https://doi.org/10.1108/09513550210448607

20. Chenhall, R.H. and Langfield-Smith, K. (2003) 'Performance Measurement and Reward Systems, Trust, and Strategic Change', Journal of Management Accounting Research, Vol.15, pp. 117-143. https://doi.org/10.2308/jmar.2003.15.1.117

21. Christiaens, J. and Rommel, J. (2008) 'Accrual Accounting Reforms: Only for Businesslike (Parts of) Governments, Financial Accountability \& Management, Vol. 24, Issue, 31, pp. 59-75. https://doi.org/10.1111/j.1468-0408.2008.00443.x

22. Chua, W. F. (1988) 'Interpretive Sociology and Management Accounting Research - A Critical Review’, Accounting, Auditing and Accountability Journal, Vol. 1, Issue 2, pp. $59-79$. https://doi.org/10.1108/EUM0000000004624

23. Cohen, L., Manion, L., Morrison, K., and Morrison, R. B. (2007), Research methods in education, Routledge, New York.

24. Cooper, G. (2008) 'Conceptualising Social Life', in Gilbert, N. (ed), Researching Social Life, Sage Publications, London, pp. 5- 20.

25. Covaleski, M.A. and Dirsmith, M. W. (1990) 'Dialectic Tension, Double Reflexivity and the Everyday Accounting Researcher: On Using Qualitative Methods’, Accounting, Organizations and Society, Vol. 15, No. 6, pp. 543-573. https://doi.org/10.1016/0361-3682(90)90034-R

26. Covaleski, M.A., Dirsmith, M. W. and Samuel, S. (1996) 'Managerial Accounting Research: The Contributions of Organizational and Sociological Theory’, Journal of Management Accounting Research, Vol. 8, pp. 1-35

27. Cresswell, J.W. (2007), Qualitative Inquiry \& Research Design: Choosing Among Five Approaches, Sage Publications, Thousand Oaks, California.

28. Denzin, N. K. (1978 a) The Research Act: A Theoretical Introductions to Sociological Methods, Mcgraw-Hill, U.S.A.

29. Denzin, N. K. and Lincoln, Y. S. (2003) 'Introduction: The Discipline and Practice of Qualitative Research', in Denzin, N. K. and Lincoln, Y. S. (eds.), The Landscape of Qualitative Research: Theories and Issues, Sage Publications Inc, London, pp. 1-46.

30. Denzin, N. K. and Lincoln, Y. S. (2008), Strategies of Qualitative Inquiry, Sage Publications, Ltd., London

31. DHCS (2007 a) Service Delivery Platform, ACT, Australia.

32. DHCS (2007b) Union Collective Agreement 2007-2010, ACT, Australia

33. DHCS (2007c) Guide to Performance Management, ACT, Australia.

34. Dooren, W. V. Bouckaert, W.G. and Halligan, J. (2010) Performance Management in the Public Sector, Routledge, London.

35. Dunleavy, P. and Hood, C. (1994) 'From Old Public Administration to New Public Management,' Public Money \& Management, July-September, 1994, pp. 9-16. https://doi.org/10.1080/09540969409387823 36. Eisenhardt, K. (1989) ‘Building Theories from Case Study Research’, The Academy of Management Review, Vol. 14, No. 4, pp. 532-550. https://doi.org/10.5465/amr.1989.4308385 
37. Ellwood, S. and Newberry, S. (2007) 'Public sector accrual accounting: Institutionalising neoliberal principles?’ Accounting, Auditing \& Accountability Journal, Vol. 20, No. 4, pp. 549-573. https://doi.org/10.1108/09513570710762584

38. English, L. (2002) 'Emasculating public accountability in the name of competition: transformations of state audit in Victoria', Critical Perspectives on Accounting, Vol. 14, Issue 1-2, pp. 51-76. https://doi.org/10.1006/cpac.2002.0523

39. Evans, M. (2018) Australian Public Service Reform: Learning from the Past and building for the future, Institute of Public Administration Australia.

40. Flick, U. (2009), An Introduction to Qualitative Research, Sage Publications Ltd., CA.

41. Flinders, D. J. (1993) 'From Theory and Concepts to Educational Connoisseurship', in Flinders, D.

42. J. and Mills, G. E. (eds.), Theory and Concepts in Qualitative Research: Perspectives from the Field, University of Chicago Press, Chicago, pp. 117-140.

43. Gaffikin, M. (2007) 'Accounting Research and Theory: The age of neo-empiricism', Australasian Accounting Business and Finance Journal, Vol. 1, No. 1, pp. 1-19 doi:10.14453/aabfj.v1i1.1

44. Gaffikin, M. (2008) 'Accounting Theory: Research, regulation and accounting practice', Pearson Education, Frenchs Forest, NSW.

45. Geertz, C. (1973) The Interpretation of Cultures, Basic Books, New York.

46. Giddens, A. (1976) New Rules of Sociological Method: A Positive Critique of Interpretative Sociologies, Basic Books, Inc., New York.

47. Giddens, A. (1979) Central Problems in Social Theory, The Macmillan Press Ltd., London.

48. Giddens, A. (1984) The Constitution of Society: outline of the theory of structuration, University of California Press, Berkeley.

49. Girishankar, N. (2001) Evaluating Public Sector Reform: Guidelines for Assessing Country-Level impact of Structural Reform and Capacity Building in the Public Sector', World Bank Operation Evaluation Department, The World Bank, Washington.

50. Glaser, B. G. and Strauss, A. L. (1968) The Discovery of Grounded Theory: Strategies for Qualitative Research, Weidenfeld \& Nicolson.

51. Guba, E. G. and Lincoln, Y. S. (1981) Effective evaluation, Jossey-Bass, San Francisco.

52. Halligan, J. (2009) 'Performance and Public Management in Australia and New Zealand', International Conference of the Institute of Public Administration, Riyadh, Kingdom of Saudi Arabia, 1-4 November.

53. Hellriegel, D. and Slocum, J. W. (1991) Management, Addison-Wesley Publishing Company.

54. Hesse-Biber, S. N. and Leavy, P. (2006) The Practice of Qualitative Research, Sage Publications, London.

55. Hood, C. (1991) 'A Public Management for all Seasons’, Public Administration, Vol. 69, Spring, 319, https://doi.org/10.1111/j.1467-9299.1991.tb00779.x

56. Hood, C. (1995) 'The New public Management in the 1980's: Variations on a Theme', Accounting, organisations and Society, Vol. 20, No.2/3, pp. 93-109. https://doi.org/10.1016/0361-3682(93)E0001-W

57. Hopper, T. and Powell, A. (1985) 'Making Sense of Research into the Organisational and Social Aspects of Management Accounting: A Review of its Underlying Assumptions', Journal of Management Studies, 22:5 September, pp. 429-465.

58. Hoque, Z. (2005) 'Securing institutional legitimacy or organisational effectiveness? A case examining the impact of public sector reform initiatives in an Australian local authority', International Journal of Public Sector Management, Vol. 18, No.4, pp.367-382. https://doi.org/10.1108/09513550510599274

59. Hoque, Z. (2006), 'Dealing with human ethical issues in research: Some advice', in Hoque, Z. ed. Methodological Issues in Accounting Research: Theories and Methods, Spiramus Press Ltd., UK, pp. 487-497.

60. Hoque, Z. (2008) 'Measuring and reporting public sector outputs/outcomes: Exploratory evidence from Australia', International Journal of Public Sector Management, Vol. 21, No.5, pp.468-493. https://doi.org/10.1108/09513550810885787

61. Hoque, Z. and Adams, C. (2011) 'The Rise and Use of Balanced Scorecard Measures in Australian Government Departments’, Financial Accountability and Management, Vol. 27, pp. 308-334. https://doi.org/10.1111/j.1468-0408.2011.00527.x 
62. Hughes, O. (1995) 'The New Public Sector Management: A Focus on Performance', in Guthrie, J. (ed), Making the Australian Public Sector Count in the 1990s, IIR Conferences Pty Ltd., NSW, pp. 140-143.

63. Humphrey, C. and Scapens, R.W. (1996) 'Methodological themes-Theories and case studies of organizational accounting practices: limitation or liberation?’ Accounting, Auditing \& Accountability Journal, Vol. 9, No.4, pp. 86-106. https://doi.org/10.1108/09513579610129435

64. Irvine, H. and Gaffikin, M. (2006) 'Methodological insights: Getting in, getting on and getting out: reflections on a qualitative research project', Accounting, Auditing and Accountability Journal, Vol. 19, No. 1, pp. 115-145. https://doi.org/10.1108/09513570610651920

65. Jacobs, K. (2012) 'Making Sense of Social Practice: Theoretical Pluralism in Public Sector Accounting Research’, Financial Accountability \& Management, Vol. 28, No.1, pp.1- 25. https://doi.org/10.1111/j.1468-0408.2011.00534.x

66. James, O. (2006) 'Public Management at the Ballot Box: Performance Information and electoral Support for Incumbent English Local Governments’, Journal of Public Administration Research and Theory, Vol. 17, Issue 4, pp. 567-580. https://doi.org/10.1093/jopart/mul020

67. Jansen, E. P. (2008) 'New Public Management: Perspectives on Performance and the Use of Performance Information', Financial Accountability \& Management, Vol. 24, Issue 2, pp. $169-191$. https://doi.org/10.1111/j.1468-0408.2008.00447.x

68. Joborne, G. O. (2006) 'Management pay, governance and performance: The case of large UK nonprofits’, Financial Accountability \& Management, Vol. 22, Issue 4, pp. $331-358$. https://doi.org/10.1111/j.1468-0408.2006.00429.x

69. Jorgensen, D. L. (1989) Participant Observation: A Methodology for Human Studies, Sage Publications, London.

70. Joyce, P. (2007) 'The integration of performance management into the management of the London Borough of Lewisham', in Longo, F. and Cristofoli, D. (eds.), Strategic Change Management in the Public Sector: An EFMD European Case Book, John Wiley \& Sons Ltd.

71. Kaplan, D. and Manners, R. (1986) Culture Theory, Waveland Press Prospect Heights, IL., USA.

72. Karreman, D. and Alvesson, M. (2004) 'Cages in Tandem: Management Control, Social Identity, and Identification in a Knowledge-intensive Firm’, Organization, Vol. 111, pp. $148-175$. https://doi.org/10.1177/1350508404039662

73. Kearney, R. (2018) Public Sector Performance Management, Motivation and Measurement, Routledge, New York.

74. Keating, P. J. (1993) Performance and Accountability, 1 July, Canberra.

75. Kimura, S. and Mourdoukoutas, P. (2000) 'Effective integration of management control systems for competing in global industries’, European Business Review, Vol. 12, No. 1, pp. 41-45. https://doi.org/10.1108/09555340010307558

76. Larbi, G. A. (2003) 'Overview of Public Sector Management Reform,' Discussion Paper 112, United Nations Institute for Social Development.

77. Layder, D. (1995) New Strategies in Social Research: An Introduction and Guide, Polity Press, Cambridge.

78. Llewelyn, S. (2003) 'Methodological Issues- What counts as "theory” in qualitative management and accounting research? Introducing five levels of theorizing', Accounting, Auditing \& Accountability Journal, Vol. 16, No. 4, pp. 662-708. https://doi.org/10.1108/09513570310492344

79. Lodh, S. C. and Gaffkin, M. J. R. (1997) 'Critical Studies in Accounting Research, Rationality and Habermas: A Methodological Reflection, Critical Perspectives on Accounting, Vol. 8, Issue 5, pp. 433-474. https://doi.org/10.1006/cpac.1996.0108

80. Luke, B.G. (2008) 'Financial returns from new public management: A New Zealand perspective', Pacific Accounting Review, Vol. 20, No. 1, pp. 29-48. https://doi.org/10.1108/01140580810872834

81. Macaulay, S. and Cook, S. (1994) 'Performance Management as the Key to Customer Satisfaction', Industrial and Commercial Training, Vol. 26, No. 11, pp. 3-8.

82. Malmi, T. And Brown, D. A. (2008) 'Management control systems as a package-opportunities, challenges and research direction’, Management Accounting Research, Vol. 19, Issue 4, pp. 287-300. https://doi.org/10.1016/j.mar.2008.09.003

83. Mason, J. (2002) Qualitative Researching, Sage Publications Ltd., London.

84. Maxwell, J. A. (2009). 'Designing a qualitative study', in Bickman, L. and Rog, D. J.(eds.) The SAGE Handbook of Applied Social Research Methods, Sage Publications, London, pp. 214- 253. 
85. McCann, W. (2001) 'Institution of Public Administration Australia: Some Observations About the Profession of Public Service', Australian Journal of Public Administration, Vol. 60, No. 2, pp. 110-115. doi/10.3316/agispt.20020536

86. Merchant, K. A. and Van der Stede, W. A. (2012) Management Control Systems, Pearson Education Limited

87. Metcalfe, L. and Richards, S. (1992) Improving Public Management, Sage Publications, London.

88. Miles, M. B. and Huberman, A. M. (1994) Qualitative Data Analysis: An Expanded Sourcebook, Sage Publications, London.

89. Mir, M. Z. and Rahaman, S. A. (2006) 'Leadership, Accounting, and the Reform Process of a Public Sector Agency: A Narrative Analysis’, Financial Accountability \& Management, Vol. 22, No. 2, pp. 157178. https://doi.org/10.1111/j.0267-4424.2006.00397.x

90. Moon, J.M. (2000) 'Organisational Commitment Revisited in New Public Management', Public Performance \& Management Review, Vol. 24, No. 2, pp. 177-194. https://doi.org/10.2307/3381267

91. Mussari, R. And Ruggiero, P. (2010) 'Public Managers' Performance Evaluation Systems and Public value Creation: Behavioral and Economic Aspects’, International Journal of public administration, Vol. 33, Issue 11, pp. 541-548. https://doi.org/10.1080/01900692.2010.507115

92. Nagy, S., Hesse-Biber, Leavy, P. (2010) The Practice of Qualitative Research, Sage Publications Inc., London.

93. National Health and Medical Research Council (1999) National statement on ethical conduct in research involving humans: Aus Info.

94. O'Reilley, C.A. and Chatman, J.A. (1996) 'Culture as social control: Corporations, Cults, and Commitment’, in Staw, B. M. and Cummings, L.L. (eds.), Research in Organisational Behaviour, Vol. 18, JAI Press, pp. 157-200.

95. Osborne, D. and Gaebler, T. (1992) Reinventing Government: How the Entrepreneurial Spirit Is Transforming the Public Sector, Addison- Wesley Reading, MA.

96. Otley, D. T. and Berry, A.J. (1980) 'Control, Organisation and Accounting', Accounting, Organizations and Society, Vol. 5, No. 2, pp. 231-244.

97. Parker, R. and Bradley, L. (2000) 'Organisational Culture in the public sector: evidence from six organisations', The International Journal of Public Sector Management, Vol. 13, No. 2, pp. $125-141$. https://doi.org/10.1108/09513550010338773

98. Patton, M.Q. (2002) Qualitative research and evaluation methods, Sage Publications, Thousand Oaks, California

99. $\quad$ Pearsall, M. (1970) 'Participant Observation as Role and Method in Behavioural Research', in Filstead, W. J. (ed), Qualitative Methodology: Firsthand Involvement with the Social World, Markham Publishing Company, U.S.A. pp. 340-352.

100. Picard, R. R. and Reis, P. (2002) 'Management control systems design: a metaphorical integration of national culture implications’, Managerial Auditing Journal, 17/5, pp. $222-233$. https://doi.org/10.1108/02686900210429632

101. Quattrone, P. and Hopper, T. (2001) 'What does organisational change mean? Speculations on a taken for granted category’, Management Accounting Research, Vol. 12, Issue 4, pp. $403-435$. https://doi.org/10.1006/mare.2001.0176

102. Rallis, S. F. and Rossman, G. B. (2012) Learning in the Field: An Introduction to Qualitative Research, SAGE Publications Inc. CA.

103. Robbins, G. (2007) 'Obstacles to implementation of New Public Management in an Irish Hospital', Financial Accountability \& Management, Vol. 23, Issue, 1, pp. 55-71. https://doi.org/10.1111/j.14680408.2007.00419.x

104. Ryan, B., Scapens, R. W. and Theobald, M. (1992) Research Method and Methodology in Finance and Accounting, Academic Press Limited, London.

105. Schutz, A. (1967) Collected Papers, Monton.

106. Soss, J., Fording, R. and Schram, S. F. (2011) 'The Organization of Discipline: From Performance Management to Perversity and Punishment', Journal of public Administration Research and Theory, Vol. 21, Issue 2, pp. 203-232. https://doi.org/10.1093/jopart/muq095

107. Stake, R. E. (2010) Qualitative research: studying how things work, The Guilford Press, NY. 108. Tooley, S. (2001) 'Observations on the imposition of New Public Management in the New Zealand state education system', in Jones, L. R., Guthrie, J., \& Steane, P. (eds.), Research in Public Policy Analysis 
and Management. Learning from International Public Management Reform, 11-A Elsevier Science, Amsterdam; Oxford, pp. 233-255.

109. Walker, R. M. and Boyne, G.A. (2010) 'Introduction: Determinants of performance in public organisations’, Public Administration, Vol. .87, Issue, 3, pp. 433-439.

110. Werbel, J. and Balkin, D. B. (2010) 'Are human resource practices linked to employee misconduct: A rational choice perspective', Human Resource Management Review, Vol. 20, Issue 4, pp. 317-326. https://doi.org/10.1016/j.hrmr.2009.10.002

111. Whitford, A. B. (2010) 'New Perspectives on Public Service Motivation: Symposium Introduction', International Public management Journal, Vol. 13, Issue 1, pp. 5-8. https://doi.org/10.1080/10967490903547118

112. Widener, S. K. (2004) 'An empirical investigation of the relation between the use of strategic human capital and the design of the management control system', Accounting, Organizations and Society, Vol. 29, Issue 3- 4, pp. 377-399. https://doi.org/10.1016/S0361-3682(03)00046-1

113. Yusuph, M.L. and Guohua, W. (2017) 'Challenges for Implementing New Public Management Reforms in Local Government in Tanzania: Evidence from Six Local Government Authorities', Public Policy and Administrative Research, Vo.7, No. 6, pp. 32-45.

114. Zawawi, N.H.M. and Hoque, Z. (2010) 'Research in management accounting innovations: An overview of its recent development', Qualitative Research in Accounting \& Management, Vol. 7, Issue 4, pp. 505-568. https://doi.org/10.1108/11766091011094554

115. Zoghbi-Manrique-de-Lara, P. (2011) 'Predicting nonlinear effects of monitoring and punishment on employee deviance: The role of procedural justice', European Management Journal, Vol. 29, Issue 4, pp. 272-282. https://doi.org/10.1016/j.emj.2011.03.003 Creative Commons Attribution - Non Commercial - No Derivatives 4.0 International License. 
